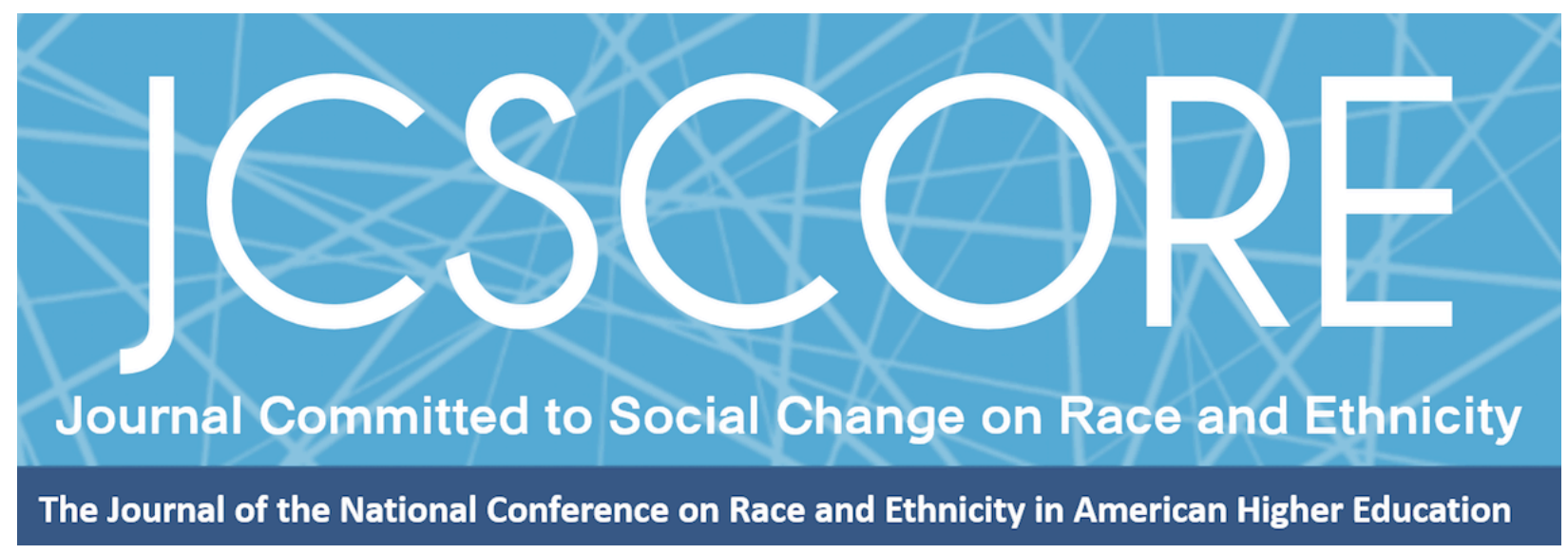

\title{
INTEREST CONVERGENCE AND THE COMMODIFICATION OF INTERNATIONAL STUDENTS AND SCHOLARS IN THE UNITED STATES
}

Christina W. Yao

University of Nebraska-Lincoln

Tiffany Viggiano

University of Jyväskylä

Journal Committed to Social Change on Race and Ethnicity

Volume 5, Issue 1 | 2019

Copyright ( 2019 Board of Regents of The University of Oklahoma on behalf of the Southwest Center for Human Relations Studies.

Permission of the Publisher is required for resale or distribution and for all derivative works, including compilations and translations. Quoting small sections of text is allowed as long as there is appropriate attribution. 


\title{
Interest Convergence and the Commodification of International Students and Scholars in the United States
}

\author{
Christina W. Yao \\ University of Nebraska-Lincoln \\ Tiffany Viggiano \\ University of Jyväskylä
}

\begin{abstract}
International students and scholars in the United States (U.S.) have often been excluded from conversations about race, ethnicity, and migration within U.S. contexts. However, with the issuance of what is commonly known as the Travel Bans, fears emerged from the international education community of the Travel Bans affecting international student recruitment and enrollment. In this study, we highlight the ways in which an official statement from leaders of international higher education organizations employ interest convergence arguments, followed by a discussion of the ways in which convergence in this case is employed as a tool to garner U.S. soft power. The examination of a brief of amicus curiae submitted by the American Council on Education and 32 additional higher education associations revealed the commodification of international students and scholars when using interest convergence as an analytical frame for examining the soft power (Nye, 2008). International students and scholars contribute to U.S. soft power as a means of garnering diversity, contributing to foreign policy, producing knowledge, and generating economic gains.
\end{abstract}

International students and scholars in the United States (U.S.) have often been excluded from conversations about race, ethnicity, and migration within U.S. contexts. However, the majority of international students who study in the U.S. may be considered Students of Color (Yao, George Mwangi, \& Malaney Brown, 2019), as the top ten countries of origin include six Asian countries, Saudi Arabia, Brazil, and Mexico (Institute of International Education [IIE], 2018b). In addition, international students are recruited within a "dominant global imaginary" (Stein \& Andreotti, 2015, p. 226) that is "rooted in Western supremacy" (p. 226) primarily for economic gain. Yet some international students and scholars, particularly those from majority Muslim countries, 
Journal Committed to Social Change on Race and Ethnicity | 2019

may be viewed by the current Presidential administration as prospective foreign terrorists who are a danger to U.S. security and safety (Executive Order No. 13769, 2017). As a result, international students are paradoxically viewed as both a commodity and a danger to U.S. policies and laws, as evidenced by contemporary Presidential Executive Orders related to immigration.

Collectively, Executive Order 13769 (2017), Executive Order 13780 (2017), and Presidential Proclamation 9645 (2017) in the United States have come to be known as the Travel Bans. Critics inside and outside of the U.S. chastise the Travel Bans for specifically targeting, among others, Muslim majority countries: Chad, Iran, Libya, North Korea, Somalia, Syria, Venezuela, and Yemen. Members of international higher education organizations have expressed fear that the Travel Bans will exacerbate an already growing trend of falling international student enrollment in the U.S. In response, multiple professional associations (e.g., NAFSA, ACE, AAU, APLU, and COGR) released statements in reaction to the Senate Judiciary Subcommittee on Border Security and Immigration hearing on June 6, 2018, which was related to international student and scholar visas and national security. The policy briefs, lobbying for international student and scholar support and recruitment, included statements such as U.S. higher education serving as "the 'gold standard' for graduate education in the world" and how international students "often serve as ambassadors for American values, democracy, and the free market" (American Council on Education, Association of American Universities, Association of Public and Land-grant Universities, \& the Council on Governmental Relations, 2018, p. 2). 
Journal Committed to Social Change on Race and Ethnicity | 2019

Indeed, current data lends credence to these fears of the Travel Bans affecting international student enrollment. Prior to the Travel Bans, international student enrollment in the U.S. reached an all-time high of over 1 million total international students in 2016-17, continuing its course as the top destination for international students (Institute for International Education [IIE], 2017). However, although the overall numbers were on an upward trajectory in recent decades, scrutiny was placed on the drop in new international student enrollment, which was a 3\% decrease from the previous year (IIE, 2017). Post-Travel Ban, in the 2017-18 academic year, the number of new student enrollments dropped for the second year in a row, down $6.6 \%$ from the previous year (IIE, 2018a). Recent data from the Council of Graduate Schools (Okahana \& Zhou, 2019) confirms the correlation between the Travel Bans and decreasing enrollment at the graduate level: first-time graduate enrollment of students hailing from the Middle East or North African countries fell by 12\% (Okahana \& Zhou, 2019).

The decline in new international student enrollment, complicated by the Travel Bans, led to discussions across the U.S. about the possible ramifications of enrollment decline. Official statements from leaders of international organizations reveal the commodification of international students and scholars when using interest convergence as an analytical frame for examining the soft power (Nye, 2008) that international students and scholars bring to the United States. In this paper, we highlight the ways in which an official statement from leaders of international higher education organizations employ interest convergence arguments, followed by a discussion on the ways in which convergence in this case is employed as a tool to garner U.S. soft power. Specifically, 
we critically examine a brief of amicus curiae (referred to as amicus brief) that was submitted by the American Council on Education and 32 additional higher education associations ${ }^{1}$, such as NAFSA: Association of International Educators and the Association of American Universities (AAU) (Brief for ACE et al., 2018). This amicus brief was submitted in response to the 2018 Supreme Court Case, Trump v. Hawaii, in which the Trump administration petitioned to uphold the executive orders and proclamations (i.e., the Travel Bans). The 33 higher education associations submitted the amicus brief in support of the respondents and made arguments against the Travel Bans. Specifically, the 33 associations, referred to as amici in this paper, shared "a strong interest in ensuring that people from all over the world... are not barred or deterred from entering the United States and contributing to American colleges and universities" (Brief for ACE et al., 2018, p. 1). This brief is significant in that major higher education associations endorsed the statements, and the brief is more detailed and

\footnotetext{
${ }^{1}$ Amici include: American Council on Education, Association of American Universities, Accreditation Council for Pharmacy Education, ACT, American Association of Collegiate Registrars and Admissions Officers, American Association of Community Colleges, American Association of State Colleges and Universities, American Association of University Professors, American Indian Higher Education Consortium, American Speech-Language-Hearing Association, Association of American Colleges \& Universities, Association of American Law Schools, Association of Catholic Colleges and Universities, Association of Governing Boards of Universities and Colleges, Association of Jesuit Colleges and Universities, Association of Public and Land-grant Universities, Association of Research Libraries, College and University Professional Association for Human Resources, Council for Advancement and Support of Education, Council of Graduate Schools, Council of Independent Colleges, Council on Social Work Education, Educational Testing Service, EDUCAUSE, Graduate Management Admissions Council, Hispanic Association of Colleges and Universities, Law School Admission Council, NAFSA: Association of International Educators, NASPA: Student Affairs Administrators in Higher Education, National Association for College Admission Counseling, National Association of College and University Business Officers, National Association of Diversity Officers in Higher Education, and National Association of Independent Colleges and Universities.
} 
Journal Committed to Social Change on Race and Ethnicity | 2019

specific than the individual short statements (if given) from higher education associations in regards to the Travel Bans. The purpose of this study is to examine this amicus brief in an effort to answer the questions: In what ways do official statements from leaders of higher education organizations in response to the travel ban demonstrate interest convergence? In what ways do these interest convergence arguments advantage U.S. soft power?

\section{International Student and Scholar Mobility for Soft Power}

International student mobility has long been employed as a tool to garner U.S. soft power. Government sponsored programs, including student recruitment, were explicitly designed to "win the hearts and minds" (Nye, 2008, p. 108) of those outside of the U.S. so as to prevent political conflict or to gain ideological supremacy. International students and scholars were conceptualized as strategic political investments and access was extended only to global elites (Altbach \& De Wit, 2015; Johnson, 2017). Pre-Cold War, during the period of liberal internationalization, the Fulbright program was designed to develop mutual understanding among nations (Altbach \& De Wit, 2015; Johnson, 2017). The Cold War explicitly politicized international student mobility as a means of garnering U.S. ideological superiority (Altbach \& De Wit, 2015; Johnson, 2017, during which Altbach and De Wit (2015) suggested that "the Third World War was the battle of international educational cooperation" (p. 7). The U.S. government sought to influence those from other nations and successfully facilitated global dominance of the English language and the dominance of Western products, structures, and frames of reference (Altbach \& De Wit, 2015). 
Journal Committed to Social Change on Race and Ethnicity | 2019

Today, there has been a shift away from this liberal idealism of international student mobility (Johnson, 2017) toward a more market driven neoliberalism, resulting in the massification of international higher education (Andreotti, Stein, Pashby \& Nicolson, 2016). The majority of international students pay for their education with personal finances (Altbach, 2016), and international students are often conceptualized as revenue sources (Altbach \& Knight, 2007). Although the U.S. government funds a smaller proportion of international student mobility than in previous decades, U.S.

interests continue to be advanced as national recruitment efforts continue to bring more international students to the U.S. than any other country, presumably cultivating an affinity amongst participants. Therefore, presumably_in accordance with Nye's (2008) theory of soft power-the U.S. continues to reap soft power benefits associated with international mobility in this era of international massification.

Nye (2008) discussed the ways in which the means of garnering soft power have changed in the information age. Successful soft power schemes tend "to be associated with intangible assets such as an attractive personality, culture, political values and institutions, and policies that are seen as legitimate or having moral authority" (Nye, 2008 , p. 95). Information is correlated with power, and a much larger share of the world population have access to information today, but the quality of that information is often unverifiable. Nye (2008) connected the information age to what Simon (1998) described as the paradox of plenty: given the abundance of information, attention becomes the scarce resource for which those vying for soft power must compete. Reputation-in the sense of not only prestige but also credibility-attracts attention and is therefore key to soft power. As such, information that turns out to be untrue or unjust will reduce soft 
power by damaging the credibility of the country. Their audience will be less willing to believe that the information provided by the government is worthy of their limited attention. As such, failing to live up to an espoused value system will damage credibility and therefore the government's ability to garner soft power, which this paper relates to international student recruitment.

To maintain soft power, the U.S. government must recurrently justify the ways in which their decisions, in this case the Travel Bans, live up to the values that their target audience admires. To do this, they engage in broadcasting and relationship building, which is currently being done through international higher education organizations. However, as Nye (2008) points out "Not only do actions need to reinforce words, it is important to remember that the same words and images that are most successful in communicating to a domestic audience may have negative effects on a foreign audience" (p. 104). As such, international organizations that garner soft power for the U.S. must find ways to navigate the interests of both a domestic and international audience. Arguments that attempt to appeal to multiple groups at once are likely to result from the pursuit of soft power.

\section{Analytical Framework: Interest Convergence}

We utilize the principle of interest convergence (Bell, 1980; Delgado \& Stefancic, 2017; Yao et al., 2019) as a tool to examine current discourse related to the commodification of international students. Interest convergence, with its roots in critical legal studies and critical race theory, was coined by Bell (1980) who posited that the majority group advances equality and justice only when it suits their own interests. The foundations of interest convergence are rooted in Bell's (1980) critique of the Brown v. 
Journal Committed to Social Change on Race and Ethnicity | 2019

Board of Education landmark case that ended state-imposed racial segregation of public schools in the United States, in which he argued that neutrality could not govern decision-making. Rather, decisions to serve and include disadvantaged groups are made based on political, economic, and social interests of dominant groups. Although subordinate groups may benefit from interest convergence, the priority of decisions and policies are always rooted in the dominance and supremacy of the dominant majority group (Bell, 1980; Delgado \& Stefancic, 2017). As such, although interest convergence arguments may appear to benefit both groups simultaneously, they in fact disprivilege those disassociated with power.

Although interest convergence was founded on the experiences of domestic People of Color, interest convergence can be extended to include international student mobility within the U.S. context as international student recruitment is often discussed as a way to contribute to the geopolitical and economic power of U.S. higher education. Application of interest convergence to international student mobility is particularly salient because contemporary theorists have used interest convergence beyond the BlackWhite binary "to apply it to the current world situation" (Delgado \& Stefancic, 2017, p. 24). The application to the world situation is appropriate as the global system is rooted in the intersections of dominance and subordination, and in this particular study, the U.S. holds a dominant position in the recruitment of international students and scholars as the top global destination (IIE, 2018a). In addition, because a majority of international students and scholars may be considered People of Color (Yao et al., 2019), the interests of the U.S. are served in international student and scholar recruitment and retention, indicating a Western dominance and supremacy of student mobility (Stein \& 
Andreotti, 2015). Higher education, particularly those situated within Western perspectives, has been "dependent on the racial/colonial violences of separation, dispossession, and containment" (Stein \& Andreotti, 2016, p. 6), maintaining the historical foundations of "deep and malleable global whiteness" (Christian, 2019, p. 179).

The U.S. is in a dominant position in the "global field of whiteness" (Christian, 2019, p. 179), as it has a high level of cultural, economic, and social capital. As a result, the U.S. continues to gain in "white economic and political control in the world-system" (Christian, 2019, p. 179) as it continues to "maneuver along a racial hierarchy of nations and categories" (p. 179). As a result, the global positioning of the U.S. as the top host country for international students and scholars contributes to national and institutional pursuits for dominance despite the contributions to global inequities related to student and scholar mobility.

The flow of international students and scholars typically feed into the Global North, with benefits including profits, international reputation, and global competitiveness (Altbach, 2016). As a result, international student mobility contributes significantly to the U.S. economy and global status. Although international students may perceive benefits from receiving their educational training in the U.S., the reality is that the primary interests of the U.S. are being served in the recruitment of international students and scholars, which contributes to the overall soft power of the nation.

\section{Methods and Methodology}

We considered the travel ban as a critical event— "a stimulus for reflection" (Angelides, 2001, p. 431)—that demonstrates the ways in which the interest 
convergence arguments employed by leaders of higher education organizations garner soft power for the U.S. at the expense of the international community. We conducted a content analysis of the 17-965 amicus brief that was assembled and submitted by " 33 associations of colleges, universities, educators, trustees, and other representatives of several thousand institutions in the United States, as well as organizations that enable and support American higher education" (Brief for ACE et al., 2018, p. 1). As such, the document represents the collective voices of international education leaders in the U.S. and findings may be generalizable beyond the document itself (Maxwell, 1992). Content analysis was appropriate for this study as it allowed us to analyze the brief to explore "the meanings, symbolic qualities, and expressive contents" as well as the "communicative roles they play" (Krippendorff, 2013, p. 49) within higher education.

Our coding process began with independent pre-coding as recommended by Saldaña (2016) as a way to identify significant passages and ideas that stood out to us. To ensure interpretive validity, we then consulted with each other to discuss and reflect on some initial observations (Maxwell, 1992). We conducted provisional coding, which used a "predetermined start list of codes" (Saldaña, 2016, p. 168) based on this study's analytical frameworks (Stemler, 2015). After preliminary review, we discussed our interpretations of the amicus brief, and then moved to pattern coding, which involved grouping "summaries into a smaller number of categories, themes, or concepts" (Saldaña, 2016, p. 236). Grounded in our theoretical framework, we identified four thematic codes to describe the multiple forms of interest convergence arguments that appeared throughout the document (Gibbs, 2007). We identified that the amici 
Journal Committed to Social Change on Race and Ethnicity | 2019

conceptualized international students as a means of garnering diversity, contributing to foreign policy, producing knowledge, and generating economic gains.

\section{Findings and Analysis}

In alignment with the theory of soft power (Nye, 2008), the amici were very concerned with the way in which the Travel Bans influenced international perceptions and therefore concrete realities. Members suggested that the Travel Bans impede national interests simply by shifting national perceptions:

Foreign students, faculty and researchers come to this country because our institutions are rightly perceived as the destinations of choice compared to all others around the globe. The Proclamation, like E0-1 and E0-2, altered those positive perceptions with the stroke of a pen... those changed perceptions quickly gave rise to new realities. (Brief for ACE et al., 2018, p. 4)

Throughout, the amici argued that it was not in the interest of U.S. soft power to maintain the Travel Bans.

As such, the overall argument of the amicus brief was one of interest convergence. The writers were interested in the benefits to the institution and nation, not to the international constituents themselves. For example, on multiple occasions the amici suggested that the primary objective of the brief was "ensuring that people from around the world, including the eight countries identified in the challenged Presidential Proclamation, are not barred or deterred from entering the United States and contributing to American colleges and universities" (Brief for ACE et al., 2018, p. 1). The amici were concerned with the "ability to attract the international students and scholars who are essential to the success of American educational institutions" (Brief for ACE et al., 2018, p. 4). Therefore, it was the contribution to the American institutions that was valued, not necessarily the benefits to the international constituents themselves. 
The amici argued that their ability to contribute to national interests would be impaired by their inability to capitalize on the benefits of internationalization. They concretely tied the general interest convergence argument to national interests, stating that "the Proclamation's unwelcoming message will impair the cross-border exchange of people and ideas that is critical to their success-and their ability to contribute to the success of the country as a whole" (Brief for ACE et al., 2018, p. 5). Rather than considering the negative influence on the international members of the institution, the amici chastised the executive orders because it puts institutional, and therefore national, interests in jeopardy. The amici conceptualize international constituents as contributing to the success of the institution and therefore the nation, thus exemplifying the principles of interest convergence.

In the following sections, we outline our findings of how the content and rhetoric in the amicus brief exemplifies the principles of interest convergence, in which the commodification of international students and scholars contributes to U.S. soft power. In our analysis, we found that when internationalization is conceptualized for the purpose of soft power, interest convergence arguments were represented as the primary motivation for arguing against the Travel Bans. We identify four specific arguments that demonstrate interest convergence-driven recruitment of international students in the U.S.: garnering diversity, contributing to foreign policy, producing knowledge, and generating economic gains.

\section{Diversity as a Resource}

The interest convergence argument rooted in diversity is the argument that unencumbered internationalization facilitates national interests. The amici assert that, 
"[m]aintaining international diversity on our campuses is critically important to the success of American colleges and universities" (Brief for ACE et al., 2018, p. 10). International diversity is conceptualized as a tool to promote domestic constituent development by promoting "both a richer understanding and a deeper appreciation of the world in which we live" (p. 10) as well as for promoting institutional quality-"[t]he inquiry, innovation, and invention that take place every day within amici's classrooms, libraries, and laboratories depend on the ability of scholars and students to travel to and from the United States" (p. 5). International constituents of the university are portrayed as useful so long as they contribute to the perceived quality of education, specifically benefitting domestic students and the diversity rationale for the United States.

As such, the amicus brief promotes the development of their national constituents through interaction with diverse international students and scholars, but fails to consider the development said international constituents. The amici argue that cross border education "promote[s] both a richer understanding and a deeper appreciation of the world in which we live..." and that "international diversity challenges all of the members of an academic community to consider and evaluate their assumptions, beliefs, and biases" (p. 10). While it could be assumed that this relationship serves to benefit both domestic and international students and scholars, the amici's argument is nationally centered. For example,

Global diversity is critical to the success of American students as they graduate and enter the modern borderless marketplace... Syrian students enrolled at American universities are undoubtedly able to contribute to their peers' understanding of the wide-ranging consequences of the civil war in Syria in a way no textbook or lecture ever could. Similarly, Iranian students offer a unique perspective on the strengths and weaknesses of the nuclear agreement and other aspects of United States foreign policy that students could not absorb by simply reading op-eds in domestic newspapers. (p. 11) 
The ways in which the Syrian and Iranian students could be benefited by exposure to U.S. students is not discussed. Thus, this passage demonstrates the way in which the amici frame international students as a tool for the development of domestic students without a reciprocal relationship.

The amici draw on Affirmative Action amicus briefs that have been employed to argue in favor of diversity on university campuses. For example, they state:

This Court has recognized the importance of such diversity, holding that universities have a compelling interest in securing the "'educational benefits that flow from student body diversity."' Fisher v. Univ. of Texas at Austin, 570 U.S. 297, 310 (2013) (quoting Grutter v. Bollinger, 539 U.S. 306, 330 (2003)). Campus diversity helps to create and maintain an "atmosphere which is most conducive to speculation, experiment, and creation. (Brief for ACE et al., 2018, p. 10)

However, this interest convergence argument is subject to a similar critique as those presented by Bell (2003) and other critical scholars about the diversity rationale. The diversity rationale promotes diversity for the purpose of advantaging the dominant and powerful group, rather than acknowledging that the disempowered are worthy of equitable treatment in their own right (Bell, 2003). Bell (2003), as well as other critical scholars, critiqued the diversity rationale for disincentivizing focus on individual students' best interests in favor of fostering a professional community that will benefit others (Brest \& Oshige, 1995; Kirkelie, 2002; Moses \& Chang, 2006).

The amici tie this diversity rationale to national interests by highlighting the ways in which the absence of diversity may detrimentally influence knowledge production.

They assert that the message of the Travel Bans--

undermines the ability of American colleges and universities to fulfill their commitment to serving their students, their communities, the United States, and the world through innovative teaching and research. That commitment relies on maintaining a consistent pipeline of the most talented international students and 
scholars, who bring with them unique skills and perspectives that inure to the benefit of their classmates, colleagues, and the communities, small and large, served by amici's member institutions. (Brief for ACE et al., 2018, p. 5)

Without the resource of international members of the institution, universities are unable to serve the interests of the U.S. Diversity is conceptualized as a necessary component of knowledge production.

\section{Foreign Policy Contributions}

The amici's interest convergence argument rooted in foreign policy rests on the idea that international students contribute to the U.S. in terms of diplomacy, the indoctrination of democratic ideals, and competition within global higher education. The amicus brief clearly identified the benefits of international students and scholars for U.S. foreign policy and diplomacy. The amici urged a reconsideration of the Travel Bans, cautioning that "the consequences to American educational institutions and our broader national interests are not (so to speak) academic. They are quite real" (Brief for ACE et al., 2018, pp. 31-32). Beyond the academic interests of U.S. higher education, further examination of the brief indicated three specific areas related to foreign policy that served as interest convergence for the U.S.: contributions to diplomacy, indoctrination of democratic ideals, and competition within global higher education.

Diplomacy contributes to U.S. soft power through its foreign policies. For example, amici made specific reference to how international students have "gone on to...assume leadership roles in governments and other organizations, both in this country and abroad" (Brief for ACE et al., 2018, p. 3). As a result, it was assumed that the U.S.-trained leaders in other countries may be more amenable to maintaining positive relationships with the United States. Despite the fact that "the benefits from 
Journal Committed to Social Change on Race and Ethnicity | 2019

these educational exports are difficult to quantify" (p. 18), the amici claimed that "presumably some diplomatic goodwill in foreign governments across the globe is a result" (Brief for ACE et al., 2018, p. 19). Interestingly, in this specific statement, international alumni of U.S. institutions are referred to as "educational exports" (Brief for ACE et al., 2018, p. 18), clearly indicating the commodification of international students as a product for U.S. benefits.

The United States has often lauded the importance of democratic ideals when considering foreign exchange and involvement (Sijapati \& Hermann, 2012). Thus, it is of no surprise that the amici made several references to how the Travel Bans may restrict the sharing of U.S. democratic ideals to international students and scholars. The amici stated that the "education of foreign-born students and the collaboration between American students and foreign-born scholars present the United States with an opportunity to promote the ideals that, together, make up the social, political, and cultural fabric of this country" (Brief for ACE et al., 2018, p. 17). Foreign dignitaries educated in the U.S. were listed, such as Juan Manuel Santos, the president of Columbia, as well as numerous prime ministers and officials. The benefit of educating these world leaders is that they "returned to their countries steeped in American democratic principles and culture" (Brief for ACE et al., 2018, p. 19), thus sharing U.S. democratic ideals with the world.

The push of U.S. democratic ideals brings an interesting dynamic as statements in this brief paint a rosy and idealistic view of U.S. society and culture. For example, the amici stated that international students and scholars "are exposed to our norms of tolerance and respect. They witness American society's steadfast commitment to 
human rights, our emphasis on education, and our dedication to the rule of law" (Brief for ACE et al., 2018, p. 18). Yet many would argue that the U.S. lacks a commitment to human rights as well as a culture of tolerance and respect (Human Rights Watch, 2018). Thus, the rhetoric of instilling democratic ideals represents the use of persuasion and soft power as a way to demonstrate the benefits of international students in the United States. In making the case that U.S. values can be spread, the amici made a clear and compelling case of interest convergence at play in stating that these "values... transmit around the world, to the benefit of the United States, when these individuals depart this country" (Brief for ACE et al., 2018, p. 18).

The push for U.S. soft power is also in the search dominance in global competition. Dominance would include keeping its position as the top destination for international students. The amici contributed to this quest for dominance by stating that "there is a 'global bidding war' for talented international students, particularly in the STEM fields" (Brief for ACE et al., 2018, p. 17). Overall, U.S. efforts in STEM education are often rooted in maintaining a position of power within the global knowledge economy, and the fear of losing international talents drives the push against the Travel Bans, once again demonstrating interest convergence. The fear of the Travel Bans was that "fewer students and scholars choose to attend our universities...[and] go instead to other countries where they will be welcomed and embraced" (Brief for ACE et al., 2018, p. 17). U.S. institutions are already losing international students to other countries as they "give substantial cash bonuses and other benefits to international scholars to entice them to leave the United States" (Brief for ACE et al., 2018, p. 17). Thus, the combination of heavy recruitment from other countries coupled with the Travel Bans 
Journal Committed to Social Change on Race and Ethnicity | 2019

may lead to significant international student decline in numbers as "universities across the country will lose highly competitive candidates from the affected countries to institutions outside of the United States" (Brief for ACE et al., 2018, p. 30).

\section{Knowledge Production}

Similar to the argument for dominance in global competition, the amici's interest convergence argument rooted in knowledge production rests on the idea that crossborder mobility is useful so long as it generates knowledge and/or prestige that benefit the U.S. For example, the amici assert that the Proclamation is detrimental to the national agenda because it impedes brain gain and innovation, which damages the reputation of the nation, stating that "institutions will struggle to maintain the level of talent and experience that makes the United States the world leader in higher education and research and development" (Brief for ACE et al., 2018, p. 12). The amici represent cross border education as a useful tool for demonstrating international superiority, which is threatened by the Travel Bans. The amici specifically stated that in the US, "this success is no accident. It is the result of many factors, one of which is the historic openness of our campuses to students, scholars, and researchers from all corners of the globe" (Brief for ACE et al., 2018, p. 5). Cross-border mobility, a necessary component of knowledge production, is useful as long as it brings prestige to the United States. Openness and inclusion of U.S. national borders are desirable so long as these goals contributes to international rankings and knowledge production.

The amici were concerned about issues of perception influencing knowledge production. The brief draws on the experience of members of the University of Rochester's Division of Solid Organ Transplantation: 
The Proclamation puts that work and this surgeon's ability to attract the talented foreign doctors who assist him in it-in severe jeopardy, even though he and his colleagues do not hail from the eight countries listed in the Proclamation. (Brief for ACE et al., 2018, p. 36)

The amici suggested that the perception of uncertainty is enough to influence this knowledge production. They found the Proclamation to be detrimental because it influences the ability of international members of the institution to produce knowledge via attracting international staff and engaging in the exchange of ideas internationally.

The importance of the international scholars was based on the knowledge that they produced, which therefore contributes to a dehumanization that privileges knowledge production. Rarely were scholars individually mentioned, but when they were, scholars were identified by their country of origin and scientific contribution with few personal characteristics:

Syrian professor and recipient of a MacArthur "Genius" grant who has, among other things, founded a company that develops systems to monitor vital signs to detect the onset of illness in the elderly... An Iranian medical professor who has developed novel methods for studying the long term risks of myocardial infarction and stroke following blood infection. (Brief for ACE et al., 2018, p. 21)

The personal lives of scholars are only considered in terms of their influence on knowledge production for the interests of the United States. In addition, little reference to international students and scholars' families were mentioned, with the exception of:

The implementation of this EO will necessarily tear families apart by restricting entry for family members who live outside of the U.S. and limiting the ability to travel for those who reside and work in the United States. Given those working conditions, many scholars will choose not to teach in this country. (Brief for ACE et al., 2018, p. 35).

Thus, the amici frame the inability to live with family as a problem of knowledge production rather than a problem of social importance. The ramification is merely that they will choose not to work in the United States. 


\section{Economic Benefits for the United States}

Unsurprisingly, the most tangible benefit of international students and scholars in the U.S. has been their contributions to the U.S economy. International students are often considered commodities in higher education, with international student recruitment efforts driven by profit because students are the largest funding source for international higher education (Altbach \& Knight, 2007). In the amicus brief, two specific areas related to interest convergence and economic benefits are identified: financial profit from international students and competition in the global marketplace.

The summary of the amici's argument cited a statement from ACE's former president Mary Corbett Broad in which she argued in a letter to John F. Kelly, Secretary of Homeland Security, that--

roughly one million international students that attend U.S. colleges and universities add to this country's intellectual and cultural vibrancy, and they also yield an estimated economic impact of $\$ 32.8$ billion and support 400,000 U.S. jobs, according to recent estimates. International students and scholars have served America well throughout our history. (Broad, 2017)

In a later section of the amicus brief, the consideration of financial profit from international students was highlighted in relation to NAFSA: Association of International Educators. NAFSA includes a searchable international student economic value tool on their website, in which they provide national and state economic values of hosting international students (NAFSA, 2019). As cited in the amicus brief, in the 2016-2017 academic year, international students contributed $\$ 36.9$ billion and over 450,000 jobs as a result of enrolling in U.S. colleges and universities (Brief for ACE et al., 2018, p. 13). Therefore, the interest of the amici is in maintaining the financial pipeline from international students into the U.S. economy. 
Journal Committed to Social Change on Race and Ethnicity | 2019

The amici also placed some responsibility on international students as a contributing factor for propelling higher education institutions into more recent financial challenges. Specifically, institutions in less desirable locations, such as the Midwestern United States, "have been forced to make budget cuts due to declines in international students" (Brief for ACE et al., 2018, p. 32) as a result of fewer enrolled international students. Yet more prestigious universities remain relatively unscathed "while international enrollments plummet at others (typically smaller, less prestigious institutions)" (Brief for ACE et al., 2018, p. 32). Thus, fighting against the Travel Bans met the interests of the amici because "As a matter of pure economics, the enrollment of international students and scholars produces considerable returns for this country" (Brief for ACE et al., 2018, p. 13).

Beyond direct contributions to the economy, international students and scholars also contribute to the overall U.S. competition in the global marketplace. International students may increase the "transnational business creation" (Ruiz, as cited in Brief for ACE et al., 2018, p. 13) as well as increase trade operations between the U.S. and students' home countries. In addition, "the U.S. economy has been further fueled by foreign-born innovators who came to this country" (Brief for ACE et al., 2018, p. 14) who chose to remain in the U.S., contributing to the overall financial well-being. The contributions include developing engineering and technology companies, employing large numbers of workers, and creating start-up companies, all of which further the interests of the U.S.' place in the global economy.

The amici emphasized the role of international students and scholars in science, technology, engineering and mathematics (STEM) fields within the U.S, economy. The 
Journal Committed to Social Change on Race and Ethnicity | 2019

U.S. has a compelling interest to remain strong in STEM fields as a competitive edge (The White House, 2018), and in fact, has an interest in seeking additional international students to major in STEM. Currently, "even with this steady influx of international talent, the pipeline of STEM students in this country is not expected to be wide enough to keep up with the rapidly expanding number of STEM jobs available" (Brief for ACE et al., 2018, p. 15). Therefore, the amici's emphasis on international students, many of whom are STEM majors, provide a persuasive argument for how the Travel Bans may detract from the overall U.S. soft power.

\section{Discussion and Conclusion}

The U.S. is currently the top destination for international students and scholars and, as a result, maintains its supremacy in international exchange. The power of the U.S. rises "in world politics because other countries want to follow it, admiring its values, emulating its example, and/or aspiring to its level of prosperity and openness" (Nye, 2008, p. 94). Thus, from the lens of soft power, it is in the best interests of the U.S. to continue to recruit and enroll international students as a way to keep its power within the global destinations rankings, indicating an interest convergence between the desires of international student to study in the top destination and the push for the U.S. to remain dominant in the global education economy. Nonetheless, we should consider the implications of arguments grounded in soft power and interest convergence.

We have demonstrated that arguments beginning from a place of soft power implicitly supports only interest convergence arguments. As noted by Bell (2003) and other scholars, interest convergence arguments are not in the best interest of the disempowered. As highlighted here, the interest convergence arguments deployed 
Journal Committed to Social Change on Race and Ethnicity | 2019

focus on institutional and national interests, but do not advocate for the interests of international students and scholars when those interests may not benefit the United States. While the amici were attempting to craft an argument in support of international students and scholars that dispelled the nationalist perceptions generated by the Travel Bans, they in fact reinforced nationalism by relying on a frame of soft power. This is to say, that interest convergence arguments dehumanized international constituents by conceptualizing them as resources for accomplishing a goal rather than members of the institutional community worthy of basic rights and support. Overall, the amici believe that "international students and scholars have served America well throughout history" (Brief for ACE et al., 2018, p. 3), clearly indicating a commodification of international students and scholars in the U.S., the majority of whom may be considered People of Color (Yao et al., 2019).

To a certain extent, the presentation of a transactional relationship undermines the pursuit of soft power by not living up to the cultural values of inclusion that international students and scholars may expect. Specifically, the amici stated that international communities are "exposed to our norms of tolerance and respect" (Brief for ACE et al., 2018, p. 18); however, as exemplified in the brief, international students and scholars are somewhat dehumanized into tools that primarily benefit the United States. International students and scholars become commodities that can generate diversity, contribute to foreign policy, engage in knowledge production, and support the U.S. economy. While these interest convergence arguments may appeal to a domestic audience, the self-serving interests outlined by 33 powerful U.S.-based higher education associations certainly may not appeal to international audiences. In alignment with 
Journal Committed to Social Change on Race and Ethnicity | 2019

Nye's (2008) conception of soft power, international boundary spanners must carefully appeal to both audiences if they are to successfully "attract the publics of other countries, rather than merely their governments" (p. 95).

Institutions of higher education have a history of facilitating purely transactional relationships with disempowered groups. While transactional relationships are greatly critiqued by critical scholars (Moses \& Chan, 2006), attention must be given to how international students and scholars become exploited as a result of institutional and national quests for soft power. This academic exploitation is rooted in historical perspectives of Western supremacy that is founded on "racialized expropriation and exploitation" (Stein \& Andreotti, 2016, p. 1). International students and scholars are objectified within a deep and malleable global whiteness, which perpetuates "the historical accumulation and continuation of white economic and political control in the world-system" (Christian, 2019, p. 179).

Because the global system of education is rooted in the intersections of dominance and subordination within Western and white supremacy, international students and scholars are mere commodities in the U.S.' self-serving interests for global prestige and dominance. As stated by Bell (1980), the majority group advances justice only when it suits their own interests. In this particular case, the majority group is represented by 33 higher education associations who represents most U.S. higher education institutions, all of whom seek to maintain soft power through the commodification of international students and scholars. As a result, the amicus brief for the support of international students and scholars indicate interest convergence based on the political, economic, and social interests of the dominant groups as a means to 
Journal Committed to Social Change on Race and Ethnicity | 2019

garnering diversity, contributing to foreign policy, producing knowledge, and generating

economic gains. The soft power of the U.S. is maintained and reified by the commodification of international students and scholars in higher education. 


\section{References}

Altbach, P. G. (2016). Global perspectives on higher education. Baltimore, MD: John Hopkins University Press.

Altbach, P. G., \& De Wit, H. (2015). Internationalization and global tension: Lessons from history. Journal of Studies in International Education, 19(1), 4-10.

Altbach, P. G., \& Knight, J. (2007). The internationalization of higher education: Motivations and realities. Journal of Studies in International Education, 1(3-4), 290-305.

American Council on Education, Association of American Universities, Association of Public and Land-grant Universities, \& the Council on Governmental Relations. (2018). Joint statement of the American Council on Education, Association of American Universities, Association of Public and Land-grant Universities, and the Council on Governmental Relations. Retrieved from https://www.acenet.edu/news-room/Documents/Joint-Statement-AAU-APLUACE-COGR-Senate-Judiciary.pdf

Andreotti, V., Stein, S., Pashby, K., \& Nicolson, M. (2016). Social cartographies as performative devices in research on higher education. Higher Education Research \& Development, 35(1), 84-99.

Angelides, P. (2001). The development of an efficient technique for collecting and analyzing qualitative data: The analysis of critical incidents. International Journal of Qualitative Studies in Education, 14(3), 429-442.

Bell, D. A. (1980). Brown v. Board of Education and the interest-convergence dilemma. Harvard Law Review, 518-533.

Bell, D. A. (2003). Diversity's distractions. Columbia Law Review, 103,1622.

Brest, P., \& Oshige, M. (1995). Affirmative action for whom? Stanford Law Review, 47(5), 855-900.

Brief for American Council on Education et al., as Amicus Curiae Supporting Respondents, Donald J. Trump, President of the United States, et al. v. State of Hawaii, et al., (2018) (no. 17-965).

Broad, M. C. (2017, January 31). ACE letter to DHS John Kelly [open letter]. Retrieved from https://www.acenet.edu/news-room/Documents/ACE-Letter-to-DHS-JohnKelly-International-Students-Scholars.pdf

Christian, M. (2019). A global critical race and racism framework: Racial entanglements and deep and malleable whiteness. Sociology of Race and Ethnicity, 5(2) 169 185.

Delgado, R. \& Stefancic, J. (2017). Critical race theory: An introduction ( $3^{\text {rd }}$ edition). New York, NY: New York University Press.

Executive Order No. 13769. (2017). Executive order protecting the nation from foreign terrorist entry into the United States. Retrieved from https://www.whitehouse.gov/presidential-actions/executive-order-protectingnation-foreign-terrorist-entry-united-states/

Executive Order No. 13780. (2017). Executive order protecting the nation from foreign terrorist entry into the United States. Retrieved from https://www.whitehouse.gov/presidential-actions/executive-order-protectingnation-foreign-terrorist-entry-united-states-2/

Gibbs, G. (2007). Analyzing qualitative data. Thousand Oaks, CA: SAGE. 
Human Rights Watch. (2018). World report 2018- United States. Retrieved from https://www.hrw.org/world-report/2018/country-chapters/united-states

Institute of International Education. (2017). International Student Enrollment Trends, 1948/49-2016/17. Open Doors Report on International Educational Exchange. Retrieved from https://www.iie.org/opendoors

Institute of International Education. (2018a). Number of International Students in the United States Reaches New High of 1.09 Million. Retrieved from https://www.iie.org/en/Why-IIE/Announcements/2018/11/2018-11-13-Number-ofInternational-Students-Reaches-New-High

Institute of International Education. (2018b). Open doors 2018 fast facts. Retrieved from https://www.iie.org/Research-and-Insights/Open-Doors/Fact-Sheets-andInfographics/Fast-Facts

Johnson, L. R. (2017). The program and the philosophy and Fulbright geography of US exchange programs since World War II. In L. Tournès and G. Scott-Smith (Eds.), Global exchanges: Scholarships and transnational circulations in the modern world, (pp. 173-185). New York, NY: Berghahn Books.

Kirkelie, S. M. (2002). Higher education admissions and diversity: The continuing vitality of Bakke v. Regents of the University of California and an attempt to reconcile Powell's and Brennan's opinions. Willamette Law Review, 38, 615-656.

Krippendorff, K. (2013). Content analysis: An introduction to its methodology ( $3^{\text {rd }}$ edition). Thousand Oaks, CA: Sage.

Maxwell, J. A. (1992). Understanding and validity in qualitative research. Harvard Educational Review, 62(3), 279-301.

Moses, M. S., \& Chang, M. J. (2006). Toward a Deeper Understanding of the Diversity Rationale. Educational Researcher, 35(1), 6-11.

NAFSA: Association of International Educators. (2019). NAFSA international student economic value tool. Retrieved from http://www.nafsa.org/Policy and Advocacy/Policy Resources/Policy Trends an d Data/NAFSA International Student Economic Value Tool/

Okahana, H., \& Zhou, E. (2019). International graduate applications and enrollment: Fall 2018. Washington, DC: Council of Graduate Schools.

Presidential Proclamation No. 9645. (2017). Presidential proclamation enhancing vetting capabilities and processes for detecting attempted entry into the United states by terrorists or other public-safety threats. Retrieved from https://www.whitehouse.gov/presidential-actions/presidential-proclamationenhancing-vetting-capabilities-processes-detecting-attempted-entry-unitedstates-terrorists-public-safety-threats/

Saldaña, J. (2016). The coding manual for qualitative researchers ( $3^{\text {rd }}$ ed.). Thousand Oaks, CA: Sage.

Sijapati B., \& Hermann M. G. (2012). Learning democracy: International education and political socialization. In S.S. Brown (Ed.), Transnational transfers and global development (pp. 148-162). London, UK: Palgrave Macmillan.

Simon, H. A. (1998). Information 101: It's not what you know, it's how you know it. Journal for Quality and Participation, 21(4), 30-33.

Stein, S., \& Andreotti, V. (2016). Higher education and the modern/colonial global imaginary. Cultural Studies $\leftrightarrow$ Critical Methodologies, 17(3), 1-9. 
Stein, S., \& Andreotti, V. (2016). Cash, competition, or charity: International students and the global imaginary. Higher Education, 72(2), 225-239.

The White House. (2018, December 4). America will win the global competition for STEM talent. Retrieved from https://www.whitehouse.gov/articles/america-willwin-global-competition-stem-talent/

Yao, C. W., George Mwangi, C. A., \& Malaney, V. K. (2019). Exploring the intersections of transnationalism and Critical Race Theory. Race, Ethnicity, and Education, 22(1), 38-58. 